Research Article

\title{
Public-Private Partnerships in the Electric Vehicle Charging Infrastructure in China: An Illustrative Case Study
}

\author{
Kun Wang (iD) and Yongjian $\mathrm{Ke}^{2}$ \\ ${ }^{1}$ Faculty of Architectural, Civil Engineering and Environment, Ningbo University, Ningbo, Zhejiang, China \\ ${ }^{2}$ School of Built Environment, University of Technology Sydney, Ultimo, NSW, Australia \\ Correspondence should be addressed to Kun Wang; wangkun@nbu.edu.cn
}

Received 17 April 2018; Accepted 21 June 2018; Published 8 July 2018

Academic Editor: Dong Zhao

Copyright ( $) 2018$ Kun Wang and Yongjian Ke. This is an open access article distributed under the Creative Commons Attribution License, which permits unrestricted use, distribution, and reproduction in any medium, provided the original work is properly cited.

\begin{abstract}
Effective supply of charging infrastructure is a necessary support for the development of electric vehicle and also an important strategic measure to promote energy consumption revolution and green development. The construction and operation of charging infrastructure in China is unfortunately not smooth, lagging behind the actual demand. Public-Private Partnerships (PPPs) may offer a promising way forward and accelerate the development of charging infrastructure by tapping the private sectors' financial resources and professional skills. However, PPP has not been commonly adopted in this sector yet. This paper hence studied an illustrative case of Anqing Project in China to demonstrate how governments structure a PPP deal in the electric vehicle charging infrastructures. A content analysis was conducted on the important project documents to investigate key elements including the planning, construction, risk sharing, profit distribution, and supervision during the execution stage. Based on the illustration, some key lessons and recommendations were provided to offer a reference for future charging infrastructure PPP projects in China.
\end{abstract}

\section{Introduction}

China's newly developed urban electric vehicle charging infrastructure provides power through high-voltage centralized charging stations and low-voltage decentralized charging piles. This infrastructure is an important baseline for the popularization of electric vehicles, whose development and adoption can accelerate the replacement of fossil fuels and reduce automotive exhaust emissions, helping to ensure energy security, promote emissions reduction, and prevent air pollution. The promotion of charging infrastructure in China is therefore an urgent strategic measure underlying the energy consumption revolution and green development.

As of the end of 2016, China had nearly 150,000 public charging piles, more than twice the number in 2015, making China a global leader in developing charging infrastructure [1]. Although charging infrastructure in China is large in absolute terms, it lags well behind the rate of electric vehicle development (Figure 1). The electric vehicles in proportion to charging infrastructure in Figure 1 refer to the number of electric vehicles sharing a public charging pile. This ratio is important for decision-makers to determine the number of public charging piles to be built according to the existing and expected numbers of electric vehicles. It also influences the customers' willingness to purchase and use electric vehicles. To the best knowledge of the authors, there is no universally accepted threshold value of the ratio. Given the strong strategic promotion of using electric vehicles, the Chinese government stated a goal of constructing 500,000 new public charging piles from 2015 to 2020, which however remains far from being achieved. The lack of charging infrastructure is considered a significant barrier for the wide acceptance of electric vehicles [2]. Being a quasipublic good, the initial investment from the government is large but insufficient, so a strong inflow of private capital is required [3].

Public-Private Partnership (PPP) is a long-term contract between a public party and a private party, for the development 


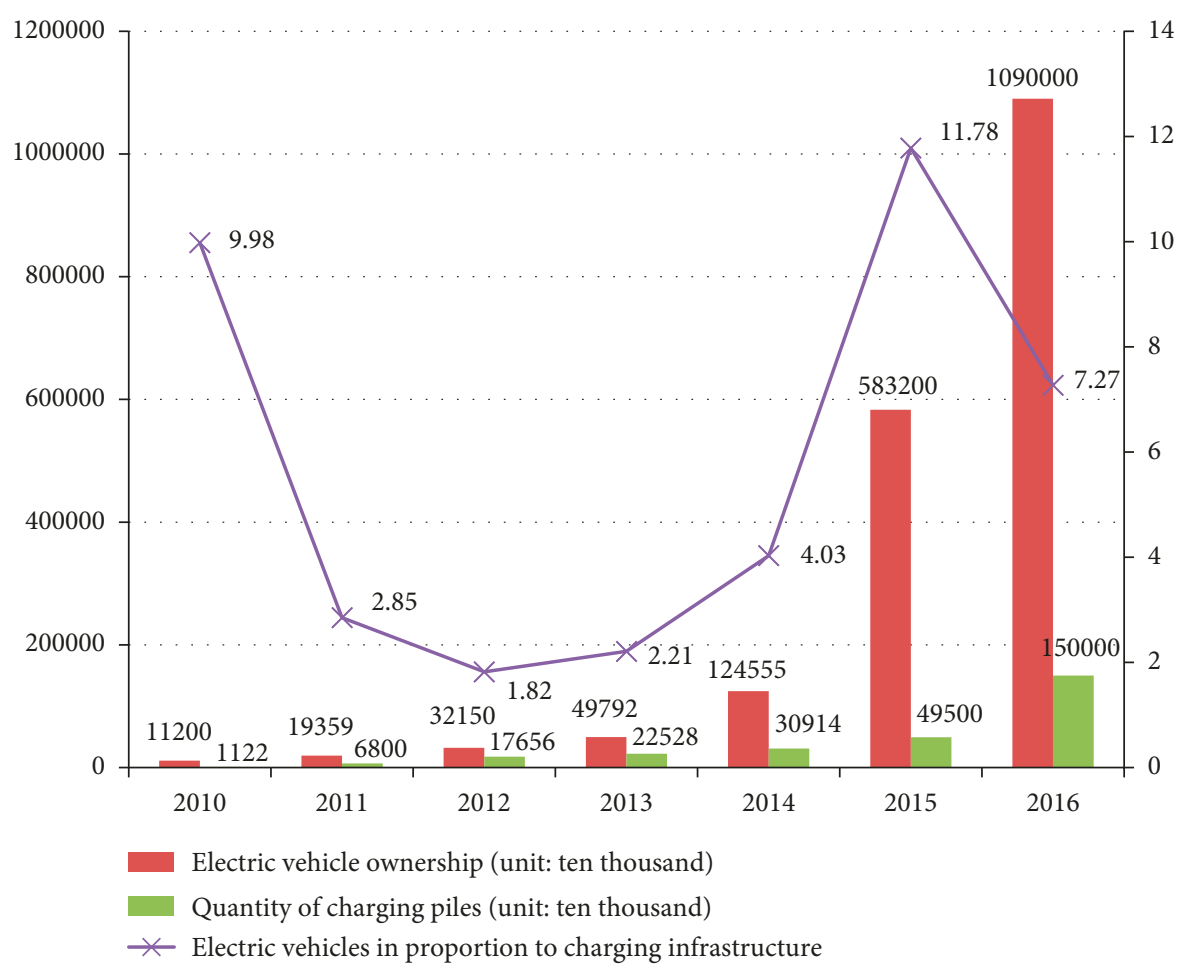

Figure 1: Electric vehicles in proportion to charging infrastructure in 2010-2016.

and management of a public asset or service, in which the private party bears significant risk and management responsibility through the life of the contract [4]. PPP may offer a promising way forward and accelerate the development of charging infrastructure by tapping the private sectors' financial resources and professional skills. However, PPP has not been commonly adopted in this sector in China yet. In the project database with a size of 14,424 projects operated by the Ministry of Finance (MOF) as of December 31, 2017, there were only 14 electric vehicle charging infrastructure PPP projects, of which three were procured [5]. It is not clear how the government should structure a PPP deal in the electric vehicle charging infrastructure to achieve value for money due to its significant differences with other infrastructure sectors such as transport, water, waste, and gas where it is common to see examples of PPP implementations. This paper hence aims to analyze the deal structure of an electric vehicle charging infrastructure PPP project, investigate key elements during the execution stage, and obtain key lessons and recommendations. By providing practitioners and academics with a better understanding of the differences between electric vehicle charging infrastructure PPPs and other PPPs, this paper expects to offer a reference for future charging infrastructure PPP projects.

\section{Literature Review}

2.1. Electric Vehicle Charging Infrastructure in China. Public charging infrastructure is a key to growing the electric vehicle market. In recent years, the central government has issued several relevant policies to support the construction of the electric vehicle charging infrastructure, such as Guiding Opinions on Accelerating the Electric Vehicle Charging
Infrastructure Construction issued by the General Office of the State Council in October 2015 and Guidelines on Development of the Electric Vehicle Charging Infrastructure (2015-2020) issued by the National Development and Reform Commission in November 2015. These government documents are constituted to demonstrate the administrative processes for land acquisition, public funding, approvals, business operation, and so on. The charging infrastructure being developed in China includes centralized charging stations and decentralized charging piles at public charging stations, as well as public charging piles and private charging piles in public transportation, sanitation, rental, engineering, logistics, and other areas [3].

The numbers of charging piles and stations have increased but their growth has not matched that of electric vehicles (as shown in Figure 1). Because the gap between supply and demand of charging infrastructure is broadening increasingly, the charging infrastructure industry must undergo an explosive growth, which has been reflected in the government's strategic plan. According to the requirements in the Guidelines on Electric Vehicles Charging Infrastructure Development (2015-2020), the number of charging piles and stations should exceed 4.8 million and 12,000 by 2020 , respectively, which are 154 times and 15 times the existing levels. The investment demand window in the charging infrastructure will hence be opened.

Compared to other infrastructure sectors, electric vehicle charging infrastructure has the following unique characteristics: it requires a large initial investment as well as a long-term operation and maintenance investment [3]; it requires a strong coordination with the smart city planning, power grids, and an intelligent transportation layout, which 
involves multiple stakeholders, high complexity, and difficulties with promotion [6]; it is exposed to various risks including changes in policies, business default, technical risks, security, market uncertainty, price adjustment risks and so on [7]; the technological advances such as battery production and electricity storage technology, wireless payment, and management are updated constantly [8].

2.2. International Practices in Electric Vehicle Charging Infrastructure. Along with the promotion of electric vehicles, many governments at both national and local levels have recognized the importance of charging infrastructure and proposed different development programs. However, these programs vary widely in scope and focus. Hall and Lutsey summarized the international practices in developing electric vehicle charging infrastructure [9], which indicates the fact that PPP is not commonly adopted in this specific sector internationally. Because electric vehicle charging infrastructure is not necessarily the responsivity of governments, governments and private companies have both been constructing public charging infrastructure for several years in many countries. In addition, all recommendations must naturally be tailored to fit local political, geographic, and demographic contexts for each country. Therefore, international practices of charging infrastructure PPP projects are not selected to study in this paper because of the research purpose.

2.3. PPP Implementations in China. PPP has been extensively used to deliver an array of infrastructure projects in China since 1980s. Cheng et al. divided the development history of PPPs in China into four phases based on the national macroeconomic environment, relevant milestone policies, and statistical analysis of their self-collected database, that is, phase one-exploration (1984-2002), phase two-stable expansion (2003-2008), phase three-development with fluctuations (2009-2013), and phase four-new boom (end of 2013 to current) [10]. In phase one, PPP was mainly applied in transportation, energy, water, and waste treatment sectors; the main player was foreign investors with mature technologies and management skills; Build-Operate-Transfer (BOT) was the most common contract type. In phase two, PPP was applied mainly in municipal utilities, such as water supply, sewage treatment, garbage disposal, and heat supply; stateowned companies and private investors took the leading role while foreign investment declined its share significantly. In phase three, state-owned companies absolutely dominated the PPP market given the fact that they possessed more government resources, by being highly affinitive with local governments and more favored by state-owned commercial banks. In phase four, China is catching a PPP fever due to the strong promotion by the central government. The PPP environment has been improved significantly, including a PPP project database established by the MOF, a PPP center formed under the MOF, a series of rules and regulations issued to clarify issues like value for money, public affordability, information disclosure, and hundreds of national PPP demonstration projects to illustrate the best practices.
2.4. PPPs in Electric Vehicle Charging Infrastructure in China. The revenue from end-users cannot cover the construction and operation costs in a charging infrastructure project. In order to deliver such a project via PPP mode, a government fund is needed to close the investment gap $[3,11]$. Therefore, compared to other economic infrastructure sectors such as power, toll road, and water, the charging infrastructure was not favored by both the public and private sectors. Along with the rapid development of PPPs since 2013, subnational governments started to explore the opportunity of using PPPs in many other sectors including the charging infrastructure. Currently, PPP in charging infrastructure in China is at its initial stage, in which the governments are enthusiastic, and the participation degree of private sector is increasing $[7,12]$. Therefore, the planning, construction, risk sharing, profit distribution, and supervision during the execution stage need to be further studied. As of December 31,2017 , among the total 14,424 projects accounting for 18.2 trillion yuan in the project database operated by the MOF, there were only 14 electric vehicle charging infrastructure PPP projects, representing only $0.097 \%$ of the total project number and $0.027 \%$ of the total investment amount. Among the 14 projects, three projects have been procured, three projects have been approved and are being prepared for procurement, and the rest are still at the project identification stage. Table 1 summarizes the six approved electric vehicle charging infrastructure PPP projects. The payment mechanism of viability gap funding denotes that the government will make PPP projects financially viable by dedicating a portion of its budget to fund the gap between the expected project revenues and costs.

\section{Research Methodology}

The PPP model will be increasingly applied to the development of the electric vehicle charging infrastructure in China. But so far, only three PPP projects have been procured. To the best of the authors' knowledge, little effort has been seen in the research of PPP application in this sector. Therefore, it is urgent to know what the lessons are in the few existing projects, and a qualitative case study approach will be appropriate for the research purpose. According to Eisenhardt and Graebner and Yin, a case study is appropriate when existing theories or the available data are insufficient to engage in quantitative hypothesis testing and when the researcher desires to gain an in-depth understanding of a complex phenomenon within its specific context $[13,14]$.

As shown in Table 1, there are six approved electric vehicle charging infrastructure PPP projects in China, of which three are still being prepared for procurement and are hence excluded first. The Kaili project, the Anqing project, and the Liupanshui project were procured in March 2015, June 2016, and July 2017, respectively. Because most information of the Liupanshui project has not been disclosed yet (and will be disclosed within six months after its execution stage according to the MOF project database), and most information of the Kaili project is not available (and may not disclosed as no disclosure plan is given in the MOF project database), the Anqing project has the richest public-available information 
TABLE 1: Overview of the existing charging infrastructure PPP projects.

\begin{tabular}{|c|c|c|c|c|c|c|c|}
\hline Project name & $\begin{array}{l}\text { Current } \\
\text { stage }\end{array}$ & $\begin{array}{l}\text { Launch } \\
\text { time }\end{array}$ & $\begin{array}{c}\text { Investment amount } \\
\text { (million yuan)/(million } \\
\text { US dollars) }\end{array}$ & $\begin{array}{c}\text { Concession } \\
\text { period } \\
\text { (years) }\end{array}$ & Modalities & Scope of work & $\begin{array}{l}\text { Payment } \\
\text { mechanism }\end{array}$ \\
\hline & & & & & & Public charging piles: & \\
\hline $\begin{array}{l}\text { (1) Anqing electric } \\
\text { vehicle charging } \\
\text { infrastructure project }\end{array}$ & Procured & 01-2016 & $818 / 124.58$ & 13 & $\begin{array}{l}\text { Regional } \\
\text { concession }\end{array}$ & $\begin{array}{l}1700 \\
\text { Bus charging stations: } 4 \\
\text { (100 dc charging piles) } \\
\text { (short-term) }\end{array}$ & $\begin{array}{l}\text { Viability gap } \\
\text { funding }\end{array}$ \\
\hline $\begin{array}{l}\text { (2) Liupanshui electric } \\
\text { vehicle charging } \\
\text { infrastructure project }\end{array}$ & Procured & 03-2016 & $210.92 / 32.23$ & 20 & BOOT & $\begin{array}{l}\text { Public charging piles: } \\
396\end{array}$ & $\begin{array}{l}\text { Viability gap } \\
\text { funding }\end{array}$ \\
\hline $\begin{array}{l}\text { (3) Kaili electric vehicle } \\
\text { charging station project }\end{array}$ & Procured & 03-2015 & $104 / 16.64$ & 20 & Not clear & $\begin{array}{c}\text { Big charging stations: } \\
12 \\
\text { Small charging stations: } \\
100\end{array}$ & \\
\hline $\begin{array}{l}\text { (4) Tianjin electric } \\
\text { vehicle charging } \\
\text { infrastructure project }\end{array}$ & Prepared & $10-2014$ & $516 / 76.08$ & 20 & BOT & $\begin{array}{l}\text { Public charging piles: } \\
2000 \\
\text { Bus charging stations: } \\
40\end{array}$ & $\begin{array}{l}\text { Viability gap } \\
\text { funding }\end{array}$ \\
\hline $\begin{array}{l}\text { (5) Kuerle electric } \\
\text { vehicle charging station } \\
\text { project }\end{array}$ & Prepared & $11-2015$ & $227.73 / 51.80$ & 30 & BOT & $\begin{array}{l}\text { Distributed charging } \\
\text { piles: } 492 \\
\text { Integrated charging } \\
\text { stations: } 16\end{array}$ & User pay \\
\hline $\begin{array}{l}\text { (6) Quanzhou electric } \\
\text { bus and charging } \\
\text { station project }\end{array}$ & Prepared & 09-2017 & $78.00 / 11.95$ & 10 & $\begin{array}{l}\text { Regional } \\
\text { concession }\end{array}$ & $\begin{array}{l}\text { Electric bus: } 120 \\
\text { Integrated charging } \\
\text { stations: } 1\end{array}$ & $\begin{array}{l}\text { Government } \\
\text { pay }\end{array}$ \\
\hline
\end{tabular}

Note: this table shows only projects that are at procured and prepared stage, and projects in the identification stage are not included because of too little information.

and was selected for a single case study in this paper. Moreover, the Anqing project is one of the national demonstration projects, which reinforces the rationality of studying this project to achieve the research purpose. $\mathrm{Na}$ tional PPP demonstration projects are selected by the MOF to highlight key examples of best practice in PPP implementations in order to further promote PPP to a larger scale. As of December 2017, there are 697 national PPP demonstration projects.

Due to limited information, a single case study method was adopted in this paper. In particular, the purpose of the study is illustrative. It is expected to demonstrate how the Chinese government structured the deal in the Anqing project, with a closer look at some key elements including the planning, construction, risk sharing, profit distribution, and supervision during the execution stage. All information and data of the Anqing project are mainly derived from important project documents including value for money report, fiscal affordability report, feasibility report, procurement documents, and PPP agreement in the PPP project database established and operated by the MOF.

\section{Case Study: the Anqing Charging Infrastructure PPP Project}

4.1. Project Background. The Anqing project, located in Anqing, Anhui province, the largest charging infrastructure PPP project executed in China, was formally signed in June 2016, later becoming a national demonstration project. It would be carried out in two phases. The first phase covers
103 square kilometers of the main city, and the second phase covers one town (Tongcheng) and six rural suburbs (Susong, Huaining, Qianshan, Yuexi, Taihu, and Wangjiang) under the jurisdiction of Anqing. By 2020, nearly 20,000 public charging piles will be built. The goal of the project is to provide public charging infrastructure and services using a smart service platform. A consortium led by Qingdao TGOOD Electric Co., Ltd., a private enterprise, was awarded the project through a competitive consultation. The private consortium is responsible for the financing, design, construction, operation, and maintenance. The payment mechanism is the method of viability gap funding, meaning that the project revenues are from user charges, and the government will dedicate its budget to fund the gap between the expected project revenues and costs. A Special Purpose Vehicle (SPV, a project company created to develop and manage the project, which is a key feature of most PPPs) was configured, in which the government's agency and private consortium hold $10 \%$ and $90 \%$ shares, respectively. The project's transaction structure is shown in Figure 2.

4.2. Project Planning. The network effect of the planning is significant. Broadly available public charging infrastructure can meet the mobility and diversity requirements of electric vehicles [11], thereby promoting the usage of electric vehicles that in turn will increase the usage of charging service [15]. In addition, the economy of scale in the electric vehicle charging service industry is apparent. In order to reduce overall operation and maintenance costs, a specific modality 


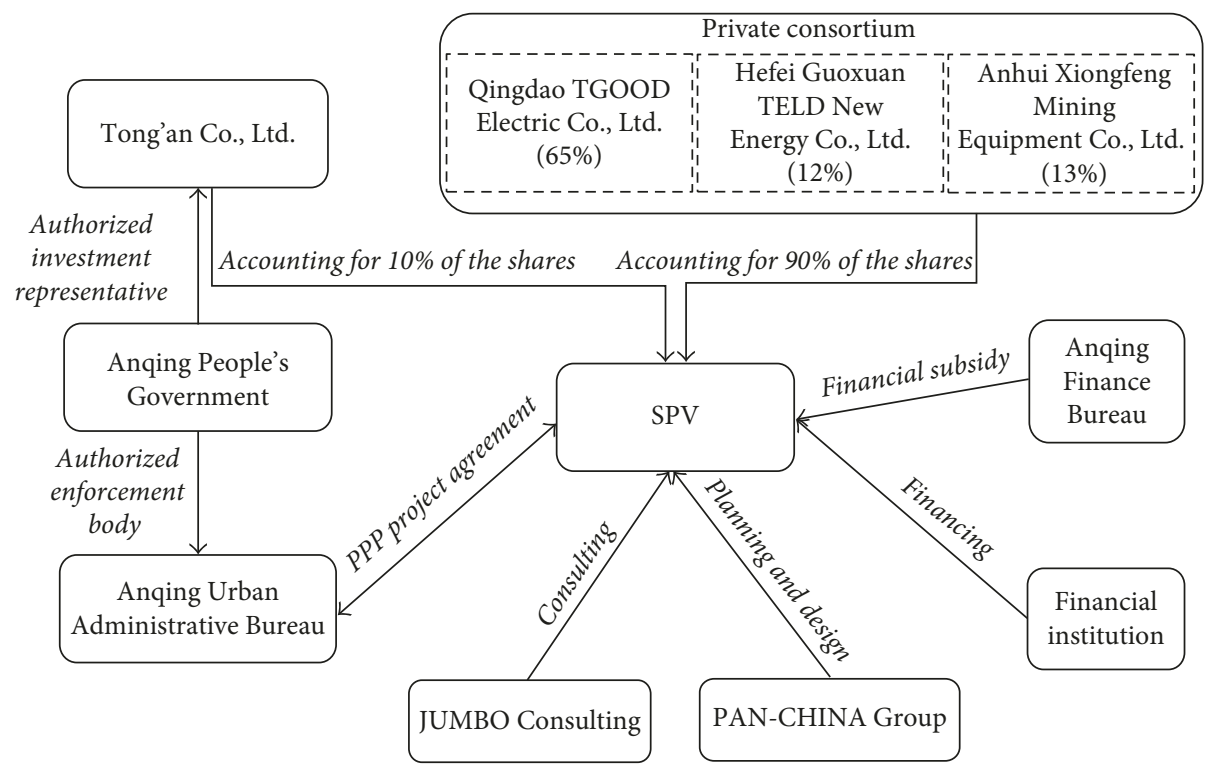

Figure 2: Project transaction structure.

of regional concession was adopted in the Anqing project. The private consortium was offered the exclusive concession right to build and operate the charging infrastructure within the defined area (i.e., 103 square kilometers of the main city, one town, and six rural suburbs). In a typical BOT project, the exclusive right is only applied to the BOT project itself with a promise of limiting competition. In this project, the exclusive right is applied to the whole defined region with a promise of not building any charging infrastructure.

Since the electric vehicles and the relevant charging infrastructure service are still under development in Anqing, it is difficult to accurately forecast the demand. Therefore, a short-term dynamic adjustment of work scope was introduced in the PPP contract of the Anqing project, which initially specified the goal of construction in 2016 being 1800 charging piles (1000 public charging piles in the main city, 100 charging piles for four bus charging stations, and 700 charging piles in one town and six rural suburbs). The construction plan for the following years during the concession period will be separately formulated and submitted to the government for implementation.

As an integral part of the future urban infrastructure system, charging infrastructure planning must be effectively coordinated with other infrastructure planning (such as electricity, transportation, informationization, etc.). At the preliminary expert review meeting for the special plan of new energy electric vehicle charging infrastructure in Anqing, electrical engineers, urban planners, and staff from the municipal planning bureau, traffic police detachment, power supply company, and other government departments were invited to participate in the joint coordination of planning. Meanwhile, the SPV was required to build an independent smart charging service platform for the project to ensure that the platform would be interconnected with the digital urban management platform of Anqing and reserve data interfaces for other provincial and national management platforms.
4.3. Construction Arrangement. Due to the requirements of abovementioned network effect and economy of scale, the construction was required to be systematically planned and optimally placed. In particular, the SPV was required to use charging equipment complying with "Connecting Device for Electric Vehicle Conduction Charging-Part 1: General requirements" (GB/T 20234.1-2015), "Connecting Device for Electric Vehicle Conduction Charging-Part 2: the AC Charging Interface" (GB/T 20234.2-2015), "Connecting Device for Electric Vehicle Conduction Charging-Part 3: the DC Charging Interface" (GB/T 20234.3-2015), and other relevant national standards. In addition, the construction of a smart charging service platform and its connection with the Anqing digital urban management platform, provincial, and national management platforms was emphasized.

One of the challenges in the construction phase lies on the decentralized construction sites, which not only caused difficulties in construction management but also resulted in the difficulties in land acquisition. There are mainly three types of construction lands in the Anqing project: (1) to build charging piles in existing private car parks, the SPV should negotiate with the land-use right holders in a marketcooperative manner with an endorsement from the government; (2) to build charging piles in existing public transport stations, the SPV should rent the land from its land-use right holders; (3) to build centralized public charging infrastructure on an independent site, Anqing Urban Administrative Bureau will coordinate the relevant departments to supply the land through an open competition process.

4.4. Risk Sharing. Major risks of the Anqing project were divided into seven categories: design/construction, operation, financial, revenue, legal, government behavior, and others. Table 2 summarizes the risk allocation between the public and private sectors. In the following paragraphs, some 
TABLE 2: Risk allocation in the Anqing project.

\begin{tabular}{|c|c|c|}
\hline Risk category & Government & SPV \\
\hline \multicolumn{3}{|l|}{ Design/construction risk } \\
\hline Planning and site selection risk & $\sqrt{ }$ & \\
\hline Land delivery and coordination risk & $\sqrt{ }$ & \\
\hline \multicolumn{3}{|l|}{ Design faults } \\
\hline \multicolumn{3}{|l|}{ Engineering technical faults } \\
\hline \multicolumn{3}{|l|}{ Labor and equipment acquisition } \\
\hline \multicolumn{3}{|l|}{ Expansion of power supply capacity } \\
\hline \multicolumn{3}{|l|}{ Construction preparation } \\
\hline \multicolumn{3}{|l|}{ General engineering variation } \\
\hline \multicolumn{3}{|l|}{$\begin{array}{l}\text { Cost overruns of construction and } \\
\text { procurement }\end{array}$} \\
\hline \multicolumn{3}{|l|}{ Completion risk } \\
\hline \multicolumn{3}{|l|}{ Site safety, environmental protection } \\
\hline \multicolumn{3}{|l|}{ Operation risk } \\
\hline \multicolumn{3}{|l|}{ Facilities' technical defects } \\
\hline \multicolumn{3}{|l|}{ Commissioning test } \\
\hline \multicolumn{3}{|l|}{ Facilities and equipment failure } \\
\hline \multicolumn{3}{|l|}{ Cost overruns of operation and maintenance } \\
\hline \multicolumn{3}{|l|}{ Quality of service do not reach the standard } \\
\hline \multicolumn{3}{|l|}{ Grid load regulation } \\
\hline \multicolumn{3}{|l|}{ Operator default and early termination } \\
\hline \multicolumn{3}{|l|}{ Overhaul and asset replacement } \\
\hline \multicolumn{3}{|l|}{ Safety management in operation period } \\
\hline \multicolumn{3}{|l|}{$\begin{array}{l}\text { Environmental protection in operation } \\
\text { period }\end{array}$} \\
\hline \multicolumn{3}{|l|}{ Financial risk } \\
\hline \multicolumn{3}{|l|}{ Financing failure } \\
\hline High financing costs & & $\sqrt{ }$ \\
\hline Interest rate change & & $\sqrt{ }$ \\
\hline Foreign exchange risk & & $\sqrt{ }$ \\
\hline Debt risk/liquidity risk & & $\sqrt{ }$ \\
\hline SPV bankruptcy & $\sqrt{ }$ & $\sqrt{ }$ \\
\hline Revenue risk & & \\
\hline $\begin{array}{l}\text { Change of electric car ownership/charging } \\
\text { infrastructure utilization ratio }\end{array}$ & $\sqrt{ }$ & $\sqrt{ }$ \\
\hline $\begin{array}{l}\text { Government pricing changes, such as service } \\
\text { fees }\end{array}$ & $\sqrt{ }$ & \\
\hline Changes in other revenue & & $\sqrt{ }$ \\
\hline Inflation & $\sqrt{ }$ & $\sqrt{ }$ \\
\hline Legal risk & & \\
\hline Contract document conflict & $\sqrt{ }$ & $\sqrt{ }$ \\
\hline Third party default & & $\sqrt{ }$ \\
\hline Government behavior risk & & \\
\hline Government default and early termination & $\sqrt{ }$ & \\
\hline Expropriation and nationalization & $\sqrt{ }$ & \\
\hline Approval delay & $\sqrt{ }$ & \\
\hline Special engineering variation & $\sqrt{ }$ & \\
\hline Tax variation & $\sqrt{ }$ & $\sqrt{ }$ \\
\hline Industry standard variation & $\sqrt{ }$ & $\sqrt{ }$ \\
\hline Technology variation & $\sqrt{ }$ & $\sqrt{ }$ \\
\hline Other risk & & \\
\hline Force majeure & $\sqrt{ }$ & $\sqrt{ }$ \\
\hline
\end{tabular}

unique risks for electric vehicle charging infrastructure projects are further explained.

4.4.1. Design/Construction Risks. The placement of charging infrastructure is an important consideration because many issues need to be addressed, including charging time, distribution, demand policies, and design standardization [16]. At present, the development of vehicles and infrastructure is not coordinated, leading to the contradictory occurrences of inconvenient charging and idle charging piles, resulting in wasted resources and low operational efficiency. Meanwhile, a large-scale unbalanced placement can have a detrimental impact on the electric grid, resulting in a significant operational risk.

Because the public charging demand is mainly located in mature central urban areas, the construction of charging infrastructure will encounter problems of demolition, property ownership, and more, such that the redevelopment cost of land is high. Meanwhile, the existing electric infrastructure may not be adequately designed to satisfy the surge in power demand necessary for increased electric service infrastructure in these areas [17], resulting in increased distribution transformer losses, voltage deviations, harmonic distortion, and peak demand [18]. The central areas of large cities in China have limited resources and so the potential for power tapping is limited. The expansion of power facilities, such as wires, transformers, and electric meters will pose a challenge to the regional power load.

4.4.2. Operational Risks. Table 2 shows all operational risks that are borne by the SPV in the Anqing project, which are the most important risks in this type of project. In the operation of charging infrastructure, factors such as cost control, efficiency improvement, charging time, and adjustments to usage demands would cause extra difficulties to operation management. Equipment replacement through technical upgrades, distribution equipment overloads caused by power demand surges, increased distribution transformer losses, voltage deviations, and harmonic distortions are some common operational risks in charging infrastructure projects [17-19].

4.4.3. Revenue Risks. According to the press, most charging infrastructure investments in China have faced losses or low returns from 2006 to 2014 [20]. The Anqing government encouraged the SPV in the PPP agreement to participate in special charging infrastructure investment, construction, and operation at residential areas or workplaces within the planning area to increase its revenue. At present, the charging price of electric vehicles in China includes two parts: the charging service fee and the electricity fee. In the Anqing project, the fees charged by the SPV are set by the government, and the SPV has no control authority on the changes of fees. Therefore, the risk of pricing changes is allocated to the government.

4.4.4. Technical Risks. Technical risks in charging infrastructure project are high. Continuous changes in technology may lead to the replacement of existing charging equipment, or even alternative technical methods, which would cause a significant additional investment. Therefore, technical risks are shared by both parties in this project. 


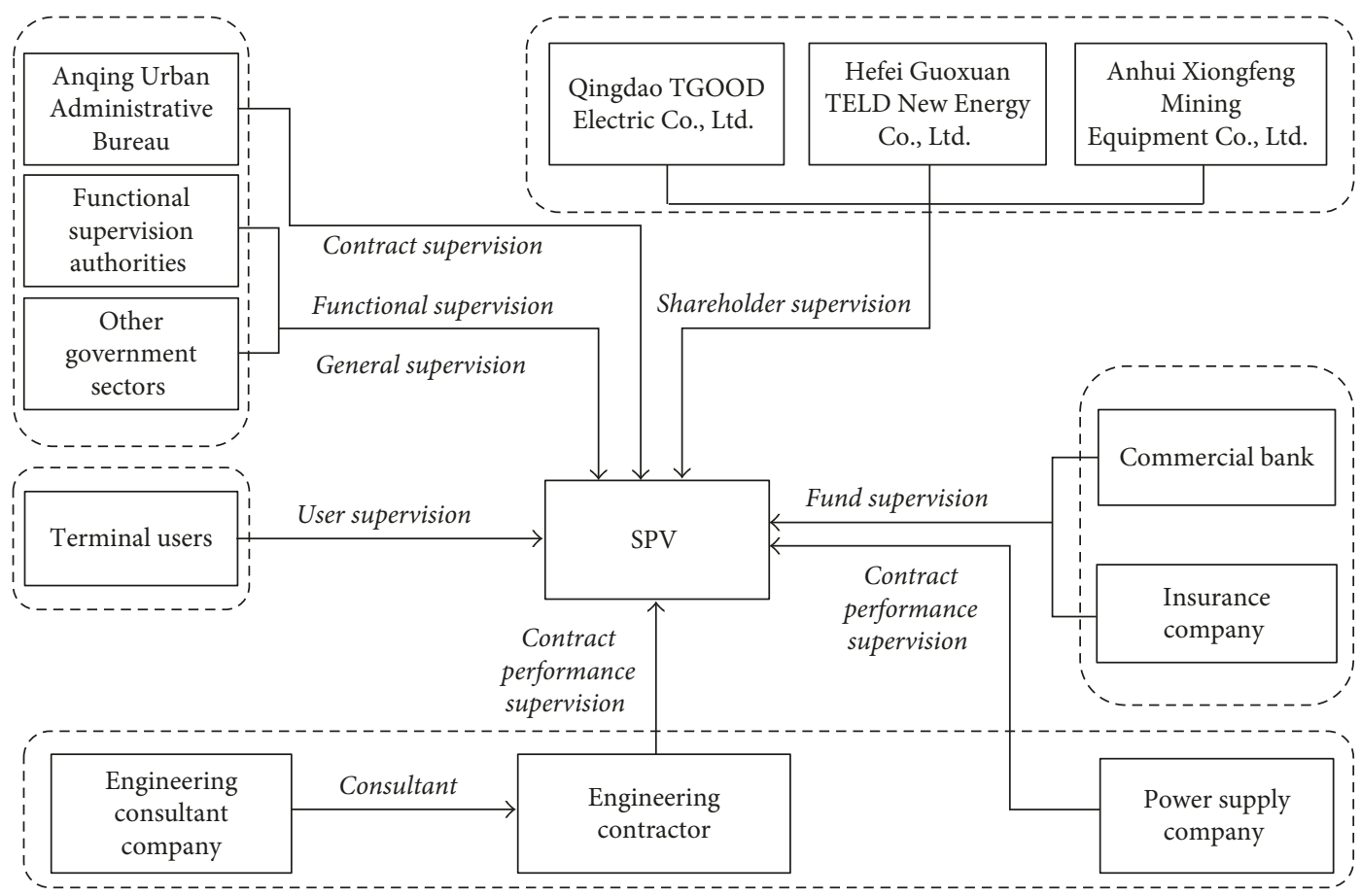

FIGURE 3: Supervision framework of the Anqing project.

4.5. Profit Distribution. In the Anqing project, the payment mechanism is the viability gap funding, including user charges and viability gap funding from the government. The former includes the electricity fee and charging service fee. During the operation period, the electricity fee is charged according to the "notice on the price of charging service for electric vehicles in Anqing" [21]. If electricity prices are changed, new prices will be adopted. The charging service fee is based on the government guidance price prior to 2020, after which it will be determined in accordance with relevant laws and policies, and through discussions with the SPV.

The viability gap funding consists of two parts: the availability and operation/maintenance subsidies. The availability subsidy is subject to the amount of construction investment and operation revenues, as well as the annual comprehensive performance assessment score. If the score is $\geq 85$ points, the subsidy will be paid in full; if the score is $<85$ and $\geq 70$ points, the subsidy will be reduced to $85 \%$; if the score is $<70$ points, the subsidy will be reduced to $70 \%$. The operation/maintenance subsidy aims to fill the gap between operational costs and revenues from the electricity and charging service fees. The Anqing PPP contract defines the following:

(1) When the charging pile utilization rate is high, meaning that the ratio of actual charging usage to expected usage is $>85 \%$ and $<115 \%$ and the project income is not enough to cover costs, the government will fully compensate for the gap; if the income is greater than cost, the government will provide no subsidy, nor will it share the excess profit.

(2) When the charging pile utilization rate is low, meaning that the ratio of actual charging usage to expected usage is $<85 \%$ and the project income is not enough to cover costs, the government will compensate $85 \%$ of the gap (thus embodying risk sharing); if the income is greater than the cost, government will provide no subsidy, nor will it share the excess profit.

(3) When the charging pile utilization rate is extremely high, meaning that the ratio of actual charging usage to expected usage is $>115 \%$ and project income is not enough to cover its costs, the government will fully compensate for the gap; if the income is greater than the cost, but the ratio of income to cost is not higher than $110 \%$, the government will not provide a subsidy, nor will it share the excess profit. However, if the ratio of income to cost is higher than $110 \%$, the government will obtain $10 \%$ of the net yield.

4.6. Supervision. Figure 3 presents the overall supervision framework for the Anqing project. The government agencies involved and supervision methods will be further explained below.

4.6.1. Government Agencies. Stakeholders involved in the supervision of the Anqing project are comprised of relevant government agencies, contracting parties, and the public (mainly the users). The government agencies include the following:

(i) Procuring authority: Anqing Urban Administrative Bureau, which signed the PPP project agreement with the SPV, will supervise and manage the 
investment, construction, and operation of the project.

(ii) Functional authorities: Anqing Development and Reform Commission, Housing and Urban-Rural Construction Committee, and Finance Bureau at all levels will supervise and manage within their respective institutional responsibilities.

(iii) Other government authorities: Electric Power Bureau, Administration of Industry and Commerce, and Public Security Bureau will supervise and manage according to their respective institutional functions and responsibilities. These agencies are less relevant to the deal structure of the Anqing project.

4.6.2. Supervision Methods. The contract management (including performance monitoring) from the procuring authority and other contracting parties, administrative supervision (including approvals) from functional government agencies and other relevant agencies, and public supervision from the general public, and more importantly end-users are the main supervision methods. These methods jointly provide an efficient and effective framework to ensure that the project achieves the expectations. During the project design and construction stages, administrative supervision dominates. It ensures that the correct processes are followed, that analysis of the proposed PPP is complete, that all the agencies that need to comment or give their approvals do so, and that the approval authorities receive all the information they need to make a sound decision. During the operation phase, one of the key activities in managing the PPP contract is to monitor project delivery and performance against output specifications. Performance monitoring and management hence performs the leading role. At this stage, public supervision also plays an important role in receiving feedback from end-users and general public for the SPV to continuously improve their charging service.

\section{Discussions}

Although the PPP model has not been widely used in the realm of charging infrastructure, the potential is great. First, compared to the traditional energy sector that is relatively monopolistic, electric vehicle charging infrastructure is a new energy industry and has fewer regulatory restraints. Second, of the fourteen PPP projects that have been identified in the PPP project database, most projects did not use government-pay mechanism. PPP is hence favored by local governments suffering severe financial burden. Moreover, the demand of charging infrastructure has been well validated along with the rapid development of electric vehicle market. On the other side, the limited implementation of PPPs in the charging infrastructure to date results in a concern of how the government should structure an electric vehicle charging infrastructure PPP project, which has been partly solved by the abovementioned illustrative case study of the Anqing project. In this section, some key lessons and recommendations are further discussed to provide a reference for future charging infrastructure PPP projects in China.

5.1. Planning a Coordinated and Dynamic Development. The planning of charging infrastructure PPP projects must take into account the network effect and the impact of economies of scale. With the continuous expansion of electric vehicle usage, the layout of charging stations and charging piles need to be optimized using a system optimization perspective and integrated in accordance with the electricity demand characteristics of mobility, diversity, and bootability. An integrated information management platform is often required to construct an efficient, intelligent, and standardized charging service network.

Electric vehicle utilization rates, user charging convenience, land supply, and other factors should be considered in the planning of site selection and quantity arrangement processes for the charging infrastructure. A scientific and systematic planning can no doubt improve the utilization of charging infrastructure, which should also be coordinated with the overall city planning, road network, and power grids. This would reduce impacts of travels for the purpose of charging on the city traffic, ensure that the power grids provide adequate power for electric vehicles, and avoid voltage limits or overloading power distribution lines/equipment.

In addition, charging infrastructure planning should adequately consider uncertainties in the initial period and adapt to the frequent updates of electric vehicle technology. The planning decision of work scope should be careful in order to avoid idleness and resource waste. The interaction between promoting electric vehicles and constructing charging facilities should be also fully considered.

5.2. Constructing with Unified Standards and Reducing Construction Costs. The unified standards related to charging infrastructure are requisite for ensuring the proper construction of charging facilities, charging safety, vehicle-pile interconnection, and payment interoperability and information exchange. In December 2015, five government departments including the National Energy Administration of China, jointly issued five newly revised national standards for electric vehicle charging interfaces and communication protocols. The levels of standards include the national standards $(\mathrm{GB} / \mathrm{T})$, industry standards $(\mathrm{NB} / \mathrm{T})$, and professional association standards (T/CEC). The content of standards covers charging interface and communication protocol, charging facilities and key equipment, charging station construction, power exchange, charging facilities operation and maintenance, operation monitoring and operation platform communication, and symbol standards. The construction of charging infrastructure must comply with these unified standards to enhance the interoperability for both the electric vehicle drivers and the SPV.

As shown in the Anqing project, the construction sites of a charging infrastructure PPP project are often scattered and located in existing buildings and stations. The construction costs are likely to increase due to the difficult coordination among different construction sites and with different 
stakeholders. However, existing urban infrastructures may provide an opportunity to reduce the construction cost if policies to streamline the construction of charging infrastructure in existing buildings are in place and the existing urban infrastructure can be transformed to provide charging service. For example, the transformation of street lights into charging facilities in Germany could save about $90 \%$ of the construction cost [1]. Therefore, opportunities for cost reduction should be carefully examined through innovative technical solutions.

\subsection{Identifying Project Risks Comprehensively and Sharing} Them Properly. PPP projects confront great risks due to their multiple participants with different objectives and interests. Therefore, the ultimate project success can only be realized when the risks have been comprehensively identified and properly shared. The Anqing project is not an exception. As presented in Table 2, the most significant risks are associated with the operation of the project. This is because most risk factors are likely to result in issues occurring at the operation stage. Due to the unique characteristics of electric vehicle charging infrastructure, such as a rapid development in recent years and frequent updates of technical solutions, the government is committed to sharing technical risks and revenue risks in the Anqing project through the contractual arrangements of a dynamic scope of work and payment mechanism, respectively.

\subsection{Building a Smart Service Platform to Provide Diversified} Services. In the Anqing project, the SPV attached great importance to the simultaneous construction of smart service charging platform and its connections with other municipal and provincial/national platforms, so that the SPV will be able to provide customers with charging navigation, status inquiries, charging reservations, cost settlement, used car trading, car washes, and other services to increase revenues.

One of the characteristics of the Anqing charging infrastructure service platform is the strong Internet connectivity, which can significantly reduce the queuing time and strengthen third party resource integration capabilities through providing live information of charging infrastructure on the Internet. Commercial value-added space will be expanded while providing convenient services for users. The private sector needs to develop a smart service platform to record the big data of customers and analyze the data to solve the operation problems and seek for new valueadded business opportunities.

5.5. Strengthening Project Supervision. The government needs to ensure the selection of right private partners that is a key to the project success. The selection criteria should include but not be limited to rich experience, strong technical, financial, and management capacity. In the Anqing project, the government emphasized technological capacity in the charging equipment supply, construction, and operation. TGOOD, the leader of the private consortium, is a Sino-German joint venture company, with a strong financial capability and a comprehensive technical capacity and rich experience in the whole industrial chain, including charging equipment supply, construction, and operation.

Furthermore, the supervision of the PPP life-cycle processes also needs to be strengthened. The charging infrastructure is not completed by a short-term centralized construction effort but is gradually expanded and improved according to the market development. Its scale is in accordance with an appropriate proportion to the overall number of electric vehicles, while construction and operation are often carried out simultaneously. Therefore, the supervision of the life-cycle process is very important, which is not only related to the quality and standard of the service provided by the project, but also related to the calculation of the subsidy for the viability gap of SPV. Thus, in the entire project concession period, performance monitoring and management (including construction performance assessment and operation performance assessment) is often involved.

\section{Conclusions and Future Research}

Charging infrastructure is an important baseline for the popularization of electric vehicles, while the introduction of PPP to this sector is conducive to the government's use of private resources by increasing the supply of and optimizing the use of charging services. However, PPP has not been commonly adopted in charging infrastructure in China. It is not clear how the government should structure a PPP deal in the electric vehicle charging infrastructure to achieve value for money due to its significant differences with other infrastructure sectors. In this paper, an illustrative case study of the Anqing project was conducted to investigate key elements including project planning, construction arrangement, risk sharing, profit distribution, and supervision during the execution stage. Based on the illustration, some key lessons and recommendations were provided to offer a reference for future charging infrastructure PPP projects, including planning a coordinated and dynamic development, constructing with unified standards and reducing construction costs, identifying project risks comprehensively and sharing them properly, building a smart service platform to provide diversified services, and strengthening project supervision. The case study can provide industry practitioners with a clear guidance of structuring a PPP project because this project has been carefully evaluated through the MOF process to be nominated as one of the national demonstration projects and is hence a good practice for the industry to learn and follow.

At present, PPP in charging infrastructure in China is at the initial stage; government sectors are enthusiastic but private investors' willingness still needs to be stimulated. As one single case study was conducted in this paper, the findings may be biased and need to be carefully examined before being applied to future PPP implementations. Due to the limited access and timeframe, interviews cannot be conducted to collect first-hand data. Therefore, more similar projects can be studied in the future, especially on the topics of how to make a coordinated and dynamic plan, methods to 
reduce execution costs, and risk management. In addition, because the selected case has been procured only for less than two years, the operation performance still remains unclear, which leads to another future research opportunity to review the project at a later stage.

\section{Data Availability}

Raw data were generated at the PPP Project Library operated by Ministry of Finance, China (http://jrs.mof.gov.cn/ppp/). Derived data supporting the findings of this study are available from the corresponding author on request.

\section{Conflicts of Interest}

The authors declare that they have no conflicts of interest.

\section{Acknowledgments}

The authors are grateful for support from the Ministry of Education Youth Project of Humanities and Social Sciences ("The correlation mechanism between relationship management and project performance in infrastructure PPP project", Grant no. 16YJCZH096) and the Soft Science Research Program of Ningbo City ("PPP model selection for new energy vehicle charging infrastructure project", Grant no. 2017A10058). This study was also sponsored by K. C. Wong Magna Fund from Ningbo University and the Chinese Scholarship Council (CSC no. 201708330424).

\section{References}

[1] Electric Vehicle Charging Infrastructure Promotion Coalition, "Electric vehicle charging infrastructure promotion coalition annual report (2016-2017)," March 2018, http://www.nea.gov. cn/136376732_14978397401671n.pdf, in Chinese.

[2] J. Beretta, C. Bleijs, F. Badin, and T. Alleau, "Electric-powered vehicles," in Automotive Electricity: Electric Drives, J. Beretta, Ed., John Wiley \& Sons, Inc., Hoboken, NJ, USA, 2013.

[3] T. Yang, R. Long, W. Li, and S. Rehman, "Innovative application of the public-private partnership model to the electric vehicle charging infrastructure in China," Sustainability, vol. 8, no. 8, pp. 738-757, 2016.

[4] World Bank, "Public-private partnerships: reference guide version 2.0," World Bank Group, Washington, DC, USA, March 2018, http://documents.worldbank.org/curated/en/ 600511468336720455/Public-private-partnerships-reference-guideversion-2-0.

[5] China Public Private Partnerships Center, "National Project Database of Integrated Information Platform for PPP," March 2018, http://www.cpppc.org:8082/efmisweb/ppp/projectLibrary/ toPPPList.do?projName=\%E5\%85\%85\%E7\%94\%B5\%E6\%A1\% A9, in Chinese.

[6] F. Vannieuwenborg, M. Tahon, S. Verbrugge, D. Colle, M. Pickavet, and P. Demeester, "Deploying charging infrastructure for electric vehicles: viability analyses for municipal and private car parking facility operators," European Journal of Transport and Infrastructure Research, vol. 14, no. 4, pp. 425-448, 2014.

[7] T. Yang, R. Long, and W. Li, "Suggestion on tax policy for promoting the PPP projects of charging infrastructure in
China," Journal of Cleaner Production, vol. 174, pp. 133-138, 2018.

[8] T. G. S. Román, I. Momber, M. R. Abbad, and Á. S. Miralles, "Regulatory framework and business models for charging plugin electric vehicles: infrastructure, agents, and commercial relationships," Energy Policy, vol. 39, no. 10, pp. 6360-6375, 2011.

[9] D. Hall and N. Lutsey, "Emerging best practices for electric vehicle charging infrastructure," March 2018, https://www. theicct.org/sites/default/files/publications/EV-charging-bestpractices_ICCT-white-paper_04102017_vF.pdf.

[10] Z. Cheng, Y. Ke, J. Lin, Z. Yang, and J. Cai, "Spatio-temporal dynamics of public private partnership projects in china," International Journal of Project Management, vol. 34, no. 7, pp. 1242-1251, 2016.

[11] Y. Zhang, Y. J. Pu, and L. F. Shi, "Construction of electric vehicle charging infrastructure and government strategy analysis," China Soft Science, no. 6, pp. 167-181, 2014, in Chinese.

[12] T. Yang, R. Long, and W. Li, "Constructing a financial environment conductive to the operation of PPP in charging infrastructure," Economic Review, no. 9, pp. 109-113, 2016, in Chinese.

[13] K. M. Eisenhardt and M. E. Graebner, "Theory building from cases: opportunities an challenges," Academy of Management Journal, vol. 50, no. 1, pp. 25-32, 2007.

[14] R. K. Yin, Case Study Research: Design and Methods, SAGE, Los Angeles, CA, USA, 5th edition, 2014.

[15] J. Neubauer and E. Wood, "The impact of range anxiety and home, workplace, and public charging infrastructure on simulated battery electric vehicle lifetime utility," Journal of Power Sources, vol. 257, pp. 12-20, 2014.

[16] M. Yilmaz and P. T. Krein, "Review of battery charger topologies, charging power levels, and infrastructure for plug-in electric and hybrid vehicles," IEEE Transactions on Power Electronics, vol. 28, no. 5, pp. 2151-2169, 2013.

[17] M. Etezadi-Amoli, K. Choma, and J. Stefani, "Rapid-charge electric-vehicle stations," IEEE Transactions on Power Delivery, vol. 25, no. 3, pp. 1883-1887, 2010.

[18] R. C. G. Li, L. Wang, and M. Alam, "The impact of plug-in hybrid electric vehicles on distribution networks: a review and outlook," Renewable and Sustainable Energy Reviews, vol. 15, no. 1, pp. 544-553, 2011.

[19] C. Farmer, P. Hines, J. Dowds, and S. Blumsack, "Modeling the impact of increasing PHEV loads on the distribution infrastructure," in Proceedings of the Hawaii International Conference on System Sciences, pp. 1-10, Koloa, Kauai, HI, USA, January 2010.

[20] Y. Tao, The Problem of Chinese-Style Charging Piles: Facing Loss Situation and Crisis after Opening, International Financial News, Shanghai, China, 2014, in Chinese.

[21] Anqing Price Bureau, Notice on the Price of Charging Service for Electric Vehicles in Anqing, March 2016, in Chinese. 


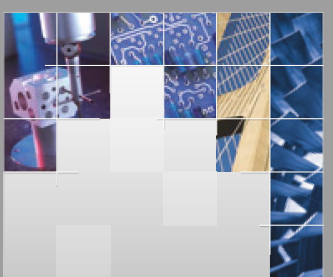

\section{Enfincering}
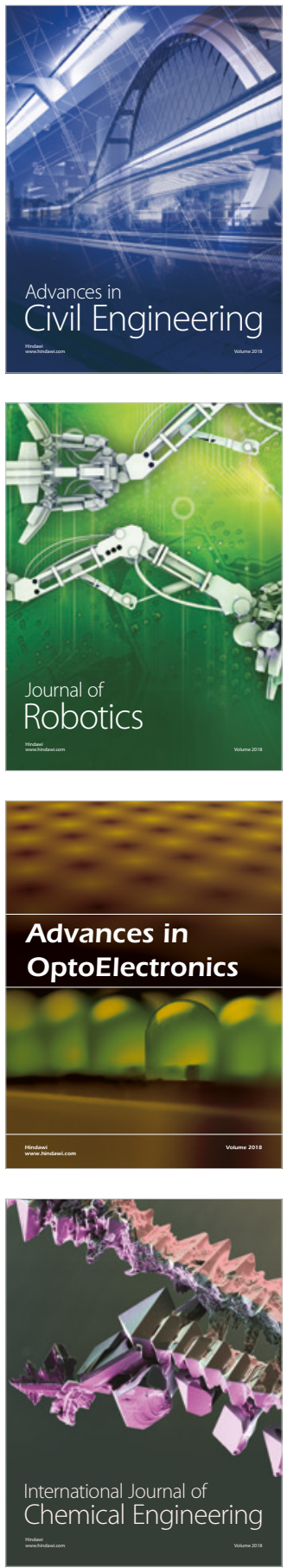

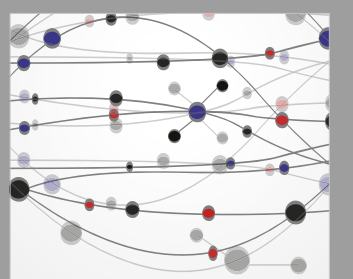

\section{Rotating \\ Machinery}

The Scientific World Journal

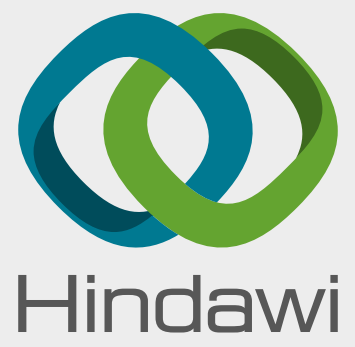

Submit your manuscripts at

www.hindawi.com
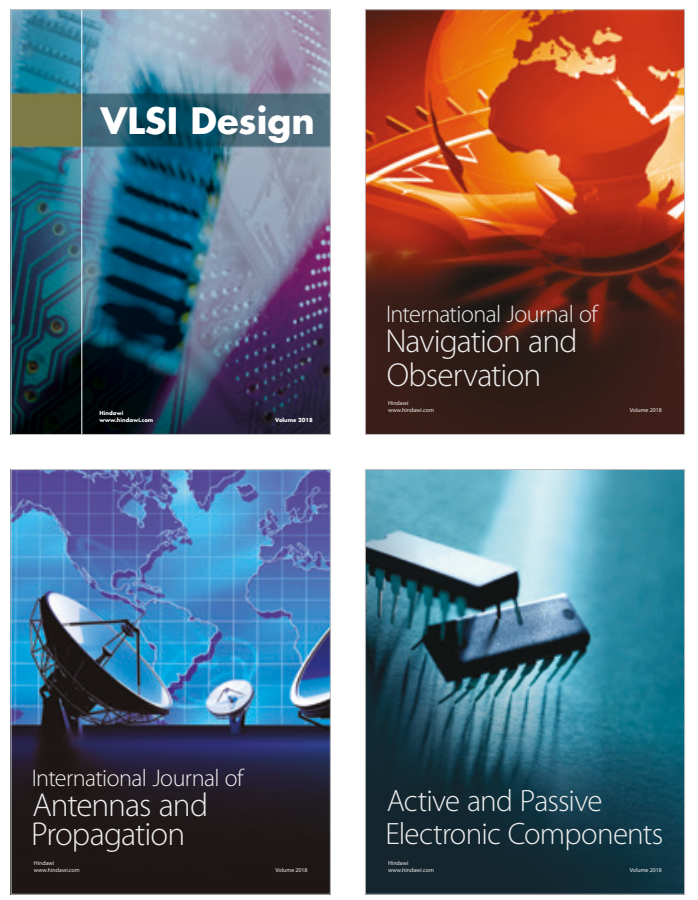
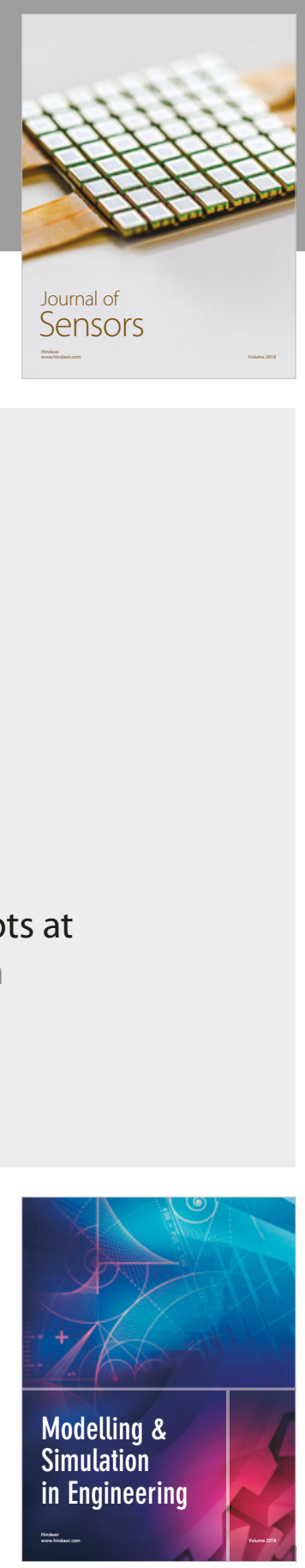

\section{Advances \\ Multimedia}
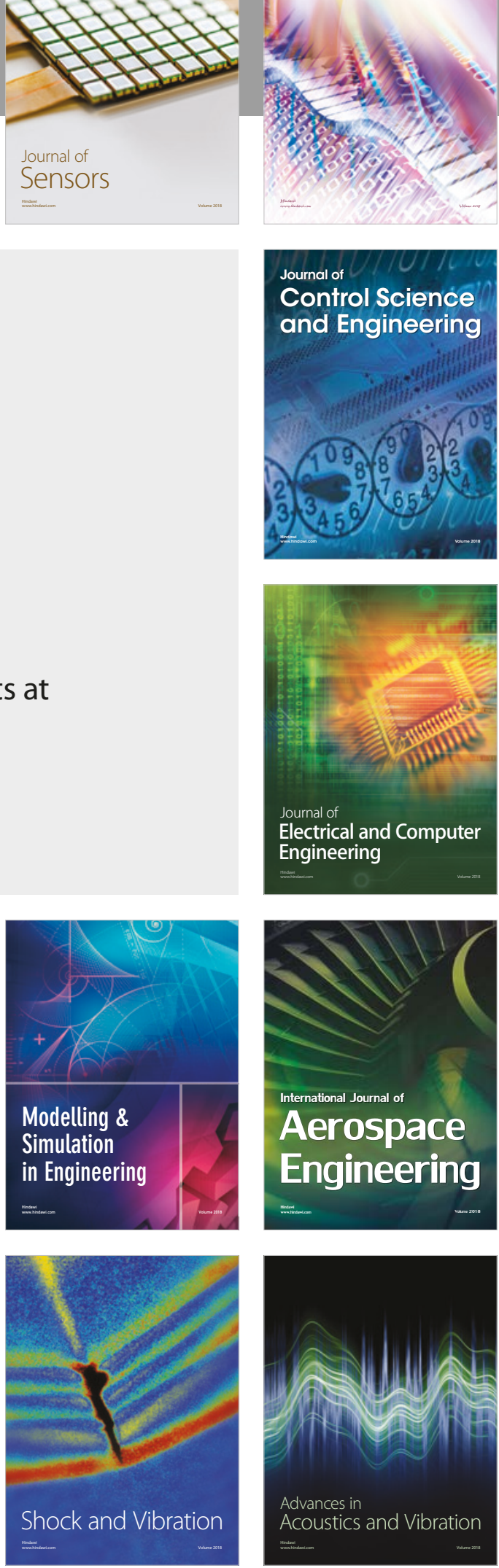